\title{
A Structural Gene for Neurospora crassa Isocitrate Lyase
}

\author{
By BRENDA J. LECKIE* AND J. R. S. FINCHAM \\ Department of Genetics, The University, Leeds, LS $29 J T$
}

(Accepted for publication 6 November 1970)

\begin{abstract}
SUMMAR Y
A purification procedure for Neurospora crassa isocitrate lyase (ICL) is described. Thirteen mutants at the acu-3 locus produced no detectable ICL activity either on sucrose as sole carbon source or in the presence of acetate. These mutants also produced little or no protein able to neutralize anti-ICL antibodies. Selection of revertants, able to grow on acetate as sole carbon source, from one of the $a c u-3$ mutants gave one class with moderately thermolabile and one with highly thermolabile ICL as well as apparently true revertants with ICL of wild-type stability. The mutants with highly labile ICL grew on acetate at $25^{\circ}$ but not at $37^{\circ}$. One of the temperature-sensitive revertants was analysed genetically and shown to be due to further mutation within or close to $a c u-3$ itself.
\end{abstract}

\section{INTRODUCTION}

Neurospora crassa can grow on acetate as sole carbon source (Flavell \& Fincham, 1968a). During growth on acetate, the glyoxylate cycle replenishes the tricarboxylic acid (TCA) cycle which generates energy and supplies metabolites to the biosynthetic pathways of the cell. The glyoxylate cycle enzymes, isocitrate lyase (ICL) and malate synthase, are present only in low (repressed) amounts during growth on sucrose, but on transfer of the mycelium to acetate, the specific activity of both enzymes increases to a higher (derepressed) level.

Fourteen mutants of Neurospora crassa which fail to grow on acetate and which lack ICL activity have been isolated (Flavell \& Fincham, I968 $a, b$ ). Malate synthase is present in these mutants. They form a single complementation group which maps at a locus designated $a c u-3$ between asp and inos on linkage group $\mathrm{V}$ of the genome. The absence of ICL activity could be due to a defect in a structural or a regulator gene for ICL, or in a gene necessary for the proper integration of ICL into a cell structure (Woodward, 1968). If $a c u-3$ is a structural gene, $a c u-3$ mutants may produce altered forms of ICL recognizable through changes in thermostability or kinetic properties or, in the absence of enzyme activity, as immunologically cross-reacting material (CRM). Mutation in an ICL regulator gene would alter the amount of ICL present without affecting its structure. Attempts to discover whether $a c u-3$ is the structural gene for ICL are described below.

* Present address: M.R.C. Blood Pressure Unit, Western Infirmary, Glasgow W. I 


\section{METHODS}

Neurospora crassa strains. The wild-type strains used were St Lawrence's ST $A$ (74 $A$ ) and sT $a$, a wild-type strain highly inbred with $74 A$; inos-6-8 $A$ had been obtained after six successive backcrosses to ST $A$ (Fincham, 1967). The acu-3 mutants were induced in inos-6-8 $A$ or ST $A$ (Flavell \& Fincham, I968a). They are identified in this paper by their original isolation numbers placed in parentheses after the $a c u-3$ symbol.

Media. Vogel's minimal medium (Vogel, 1956) was supplemented with $\mathrm{r} \%$ sucrose (sucrose medium) or with I M-sodium acetate solution to a final concentration of $40 \mathrm{~mm}$-acetate (acetate medium). Solid medium contained $\mathrm{I} \cdot 5 \%$ agar. Other supplements were added as necessary: amino acids at a concentration of $50 \mathrm{mg}$. $/ 100 \mathrm{ml}$. and inositol at $0.2 \mathrm{mg}$. $/ 100 \mathrm{ml}$. To induce colonial growth on solid medium, $0.2 \%$ sucrose and $0.9 \%$ sorbose or $0.2 \%$ sorbose and $40 \mathrm{mM}$ sodium acetate, was added to the Vogel's salt solution. Crosses were made on Westergaard \& Mitchell's crossing medium (Westergaard \& Mitchell, 1947).

$N$-methyl- $N^{\prime}$-nitro- $N$-nitrosoguanidine $(N T G)$ treatment and isolation of revertants. Five to 7 day conidia of an acu-3 inos strain were suspended in sterile water at a concentration of between $10^{6}$ and $10^{7}$ conidia $/ \mathrm{ml}$. The suspension was shaken with $0.1 \mathrm{mg} . / \mathrm{ml}$. of NTG at $30^{\circ}$ for $12 \mathrm{~min}$. This killed about $50 \%$ of the conidia. The conidia were centrifuged, washed in water, and resuspended in acetate medium + inositol $+0.1 \%$ agar to give ro times the original volume of suspension. Two ml. aliquots were pipetted into tubes, incubated at $25^{\circ}$, and the cultures which grew tested for growth on inositol; inos $^{+}$cultures were discarded. The remainder were backcrossed to an $a c u-3$ strain of opposite mating type. Single ascospores which grew on acetate were isolated, one spore being selected from each of the original revertant colonies.

Crossing procedure. One strain was allowed to grow by itself on Petri dishes for 6 days after which the resulting protoperithecia were fertilized with about $\mathrm{I} \mathrm{ml}$. of a conidial suspension of the other strain.

Growth of Neurospora crassa. Mycelium for enzyme assays was grown in $100 \mathrm{ml}$. shake cultures of sucrose medium and derepressed in the same volume of acetate medium (Fincham \& Flavell, I968a). Inositol (I mg./100 ml.) was added if required.

Enzyme assays. Extracts for assay were made by grinding mycelium with sufficient acid-washed sand and ice-cold ICL assay buffer to make a slurry. The slurry was centrifuged at $23,000 \mathrm{~g}$ for $30 \mathrm{~min}$. and the supernatant used as a crude extract.

ICL and malate synthase were measured at $30^{\circ}$ by the methods of Dixon \& Kornberg (1959). For ICL, the reaction mixture contained, in $2.6 \mathrm{ml}$., $5 \mu$ moles DL-isocitrate, Io $\mu$ moles phenylhydrazine $\mathrm{HCl}, 0 . \mathrm{I} \mathrm{ml}$. enzyme extract and $0 . \mathrm{I} \mathrm{M}, \mathrm{pH} 6.8$, sodium phosphate buffer (ICL assay buffer) containing I mM-EDTA, $5 \mathrm{~mm}-\mathrm{MgCl}_{2}$ and $0.28 \mathrm{ml}$./1. of mercaptoethanol (Sigma type 1 ). The increase in optical density at $324 \mathrm{~nm}$. was measured. For the malate synthase assay the reaction mixture contained, in $0.4 \mathrm{ml}$ : $20 \mu$ moles sodium phosphate buffer, $\mathrm{pH} 7 . \mathrm{I} ; 2 \mu$ moles $\mathrm{MgCl}_{2}, 0.025 \mu$ mole acetyl CoA and 5 to $20 \mu \mathrm{l}$. enzyme extract. The fall in optical density at $232 \mathrm{~nm}$. was measured. Units of enzyme were expressed as $\mu$ moles product per h. Specific activity of enzyme $=\mu$ moles product $/ \mathrm{h} . / \mathrm{mg}$. protein.

Protein was measured by a micro-biuret method (Itzhaki \& Gill, 1964).

Identification of the ICL band in electrophoresis gels. Acrylamide gel electrophoresis was carried out by the method of Davis (1964). Crude extracts of wild-type myce- 
lium, after derepression of the glyoxylate cycle enzymes by transfer to acetate, showed the appearance of a strong protein band which was identified as ICL by running adjacent to purified ICL in a split polyacrylamide electrophoresis gel. Similarly derepressed extracts of an $a c u-7$ mutant, thought to be defective in the $\alpha$-oxoglutarate oxidase system (Flavell \& Fincham, 1968b), gave an even stronger ICL band after similar derepression; here the ICL was the most conspicuous protein in the electrophoretic pattern. Four acu-3 mutants, numbers II, 2I, 23 and 53, were tested in a similar manner but none produced any detectable protein band in the ICL position.

CRM tests. Antibodies were induced in a New Zealand White rabbit. An extract of acetate-derepressed Neurospora crassa in 0.02 M-sodium phosphate buffer $(\mathrm{pH} 7 \cdot 4)+$ complete Freund's adjuvent was injected intrascapularly, followed by two more weekly injections of extract + incomplete Freund's adjuvent. The rabbit was bled a week after the last injection. Non-immune serum was obtained from the rabbit before the first injection. The blood was stood at room temperature for $\mathrm{I} 2 \mathrm{~h}$. and the serum was decanted, and centrifuged. It was concentrated by dialysing overnight against $24 \%$ saturated $\left(\mathrm{NH}_{4}\right)_{2} \mathrm{SO}_{4}$; the precipitate was dissolved in the minimum amount of $0 \cdot$ I $\mathrm{M}$ phosphate buffer $(\mathrm{pH} 7.0)$ and dialysed against the same buffer.

The ability of the antiserum to inhibit ICL was demonstrated by incubating serum and ICL assay buffer in a total volume of $\mathrm{I} \cdot 6 \mathrm{ml}$. with $0.025 \mathrm{ml}$. of an extract of acetatederepressed ST $A$ at $30^{\circ}$ for $30 \mathrm{~min}$. It was found that $0.05 \mathrm{ml}$. of serum inhibited $2 \cdot 2$ units of ICL by $40 \%$. No inhibition was observed when extracts were incubated alone or with non-immune serum.

The ability of extracts of acu-3 mutants to protect ICL against anti-ICL serum was tested as follows. The strain under test was grown on sucrose medium and derepressed by transfer to acetate medium. The $0.1 \mathrm{ml}$. samples of extracts which showed at least a tenfold derepression of malate synthase were each incubated with $0.05 \mathrm{ml}$. of antiserum. Then $0.025 \mathrm{ml}$. of test ICL was added, and the mixtures were reincubated and finally assayed for ICL. The remaining activity of the test ICL was compared with the activity of ICL incubated for $30 \mathrm{~min}$. at $30^{\circ}$ with $(a) 0.05 \mathrm{ml}$. antiserum and $0.1 \mathrm{ml}$. buffer, $(b) 0.05 \mathrm{ml}$. non-immune serum and $0.1 \mathrm{ml}$. buffer, (c) $0.15 \mathrm{ml}$. buffer. The amount of CRM in the extracts was expressed as units of test ICL protected/mg. of protein in the CRM extracts.

The amount of CRM in extracts of sucrose-grown and acetate-derepressed wildtype sT $A$ was also found. Amounts of ST $A$ extract were chosen so that their ICL activity was completely inhibited during the preincubation and so did not interfere with the assay of the test ICL.

Double-diffusion plates. The method of Ouchterlony (1953) was used.

\section{Purification of ICL}

(I) Preparation of extract. STA was grown from a heavy conidial inoculum on sucrose medium in a IOI New Brunswick 'Microferm' fermentor jar, collected by filtration through muslin and then transferred to acetate medium for $6 \mathrm{~h}$. before being harvested. The mycelium was frozen in liquid $\mathrm{N}_{2}$, homogenized in a Waring blender, and the frozen powder stirred into cold ICL assay buffer. The mixture was centrifuged and the supernatant was decanted and used as the crude extract. All subsequent operations were carried out at $4^{\circ}$.

(2) $\left(\mathrm{NH}_{4}\right)_{2} \mathrm{SO}_{4}$ precipitation. Solid $\left(\mathrm{NH}_{4}\right)_{2} \mathrm{SO}_{4}$ was added to the extract to $45 \%$ 
saturation, the precipitate was discarded and the supernatant brought to $35 \%$ saturation. The resulting precipitate was dissolved in a buffer similar to that used in the ICL assay, except that the phosphate was reduced to $0.01 \mathrm{M}$ and dialysed overnight against the same buffer.

(3) DEAE chromatography. The dialysed $\left(\mathrm{NH}_{4}\right)_{2} \mathrm{SO}_{4}$ fraction was applied to a column of DEAE cellulose equilibrated with the $0.01 \mathrm{M}$-phosphate buffer and eluted with the same buffer. The breakthrough fractions contained ICL and were dialysed against the $0 \cdot \mathrm{I} \mathrm{M}$-ICL assay buffer with the addition of $5 \mathrm{M}$-glycerol.

(4) Sephadex gel. The active fractions from the DEAE column were applied to the top of a Sephadex G200 column equilibrated with the O.I M assay buffer and were eluted with the same buffer. Fractions containing ICL were run through the column again; and the ICL-containing fractions from the second column were concentrated by pressure dialysis.

Studies on temperature sensitivity of revertants. Growth rates were measured at $25^{\circ}$ and $37^{\circ}$ in $1 \mathrm{~cm} . \times 30 \mathrm{~cm}$. growth tubes (Ryan, Beadle \& Tatum, I943) each containing Io $\mathrm{ml}$. of acetate or sucrose medium. To test the heat-sensitivity of ICL in vitro, extracts containing 2 to $3 \mathrm{mg}$. $/ \mathrm{ml}$. protein were made from acetate-derepressed ST $A$ and revertants. Aliquots of $0.1 \mathrm{ml}$. were heated in a water bath for $8 \mathrm{~min}$. Then $\mathrm{I} \cdot 6 \mathrm{ml}$. of assay buffer at $30^{\circ}$ was added and the mixture assayed for ICL.

\section{RESULTS}

\section{ICL purification}

The progress of the purification is shown in Table $\mathrm{x}$. The purified ICL gave a single band on polyacrylamide gel electrophoresis and a single band when run on a doublediffusion plate against antiserum to a crude extract of acetate-derepressed ST $A$. It lost activity on freezing and thawing, and at $4^{\circ}$ one preparation of the enzyme lost half of its activity in 14 days.

Table I. Progress of ICL purification

\begin{tabular}{|c|c|c|c|c|c|c|c|}
\hline Fraction & $\begin{array}{l}\text { Volume } \\
\text { (ml.) }\end{array}$ & $\begin{array}{c}\text { ICL, } \\
\text { units/ml. }\end{array}$ & $\begin{array}{l}\text { Protein } \\
\text { (mg.) }\end{array}$ & $\begin{array}{l}(\%) \\
\text { Recovery } \\
\text { of units }\end{array}$ & $\begin{array}{c}(\%) \\
\text { Recovery } \\
\text { of protein }\end{array}$ & $\begin{array}{l}\text { Specific } \\
\text { activity }\end{array}$ & $\begin{array}{l}\text { Purifi- } \\
\text { cation } \\
\text { factor }\end{array}$ \\
\hline (I) Crude extract & $I, 000$ & 90,600 & 6,500 & 100 & $100 \cdot 0$ & 15 & I.O \\
\hline $\begin{array}{l}\text { (2) } 45 \text { to } 65 \% \\
\left(\mathrm{NH}_{4}\right)_{2} \mathrm{SO}_{4} \text { precip. } \\
\text { dialysed }\end{array}$ & 70 & 88,800 & 1,620 & 83 & $25^{\circ} 0$ & 54 & $3 \cdot 6$ \\
\hline (3) DEAE column & 128 & 44,400 & I 42 & 46 & $2 \cdot 2$ & 310 & 20.6 \\
\hline $\begin{array}{l}\text { (4) Dialysis } \\
\text { (5) Sephadex: }\end{array}$ & 34 & 37,200 & 142 & 39 & $2 \cdot 2$ & 260 & - \\
\hline Col. I & II 5 & 32,400 & 67 & 34 & $x \cdot 2$ & 480 & $32 \cdot 0$ \\
\hline Col. 2 & 93 & 18,300 & 30 & 19 & 0.4 & 610 & $41 \cdot 0$ \\
\hline (6) Concentration & 14 & 7,440 & 24 & 8 & $0 \cdot 37$ & 310 & - \\
\hline
\end{tabular}

\section{CRM tests}

Table 2 shows the ability of extracts of ST $A$ and $a c u-3$ to protect ICL from anti-ICL serum. The derepressed ST $A$ extract contained Io times as much CRM as the extract from sucrose-grown mycelium. This agrees with the fact that ST $A$ derepressed extract shows about Io times as much ICL activity as sucrose-grown extract. Most acu-3 
mutants gave no detectable CRM, or a level of CRM no higher than that found in sucrose-grown ST $A$. These results were confirmed by double-diffusion plates. When extracts of acetate-derepressed ST $A$ acu-3 and pure ICL were placed in alternate wells round a central well containing anti-ICL serum, a continuous precipitin band indicating a component common to ST $A$ extract and pure ICL was observed. No band was observed with wells containing the same amount of $a c u-3$ extract; indicating that the amount of CRM in $a c u-3$ is less than the amount in acetate-derepressed ST $A$.

Table 2. Tests for CRM in acu-3 mutants grown on sucrose and acetate medium

\begin{tabular}{|c|c|c|c|c|c|c|}
\hline \multirow[b]{2}{*}{ Strain } & \multicolumn{2}{|c|}{ ICL specific activity } & \multicolumn{2}{|c|}{$\begin{array}{l}\text { Malate synthase } \\
\text { specific activity }\end{array}$} & \multirow{2}{*}{$\begin{array}{c}\text { Protein } \\
\text { tested } \\
\text { (mg.) }\end{array}$} & \multirow{2}{*}{$\begin{array}{l}\text { Amount } \\
\text { CRM }\end{array}$} \\
\hline & Sucrose & Acetate & Sucrose & Acetate & & \\
\hline $\begin{array}{l}\mathrm{sT} A \text { (wild- } \\
\text { type) }\end{array}$ & - & $9 \cdot I$ & - & $32 \cdot 0$ & 0.03 & $12 \cdot 0$ \\
\hline sT $A$ & 0.6 & - & 0.9 & - & 0.15 & $I \cdot 2$ \\
\hline$a c u-3(33)$ & 0 & 0 & $I \cdot 3$ & $20 \cdot 5$ & 0.10 & 0 \\
\hline$a c u-3(46)$ & 0 & 0 & $1 \cdot 1$ & 49.0 & 0.24 & 0 \\
\hline$a c u-3(22)$ & 0 & 0 & $I \cdot I$ & $34^{\circ} 0$ & 0.38 & 0.6 \\
\hline$a c u-3(53)^{*}$ & 0 & 0 & 0.8 & 20.0 & $0 \cdot 13$ & 0 \\
\hline$a c u-3(50) *$ & 0 & 0 & - & $38 \cdot 6$ & 0.38 & 0 \\
\hline$a c u-3(23)$ & 0 & 0 & - & 20.0 & $0 \cdot 40$ & $\mathrm{I} \cdot 2$ \\
\hline$a c u-3(178)^{*}$ & 0 & 0 & - & 20.0 & $0 \cdot 48$ & 0.3 \\
\hline acu-3 (IIS)* & 0 & 0 & - & $21 \cdot 0$ & 0.55 & 0 \\
\hline$a c u-3(I I)$ & 0 & 0 & $1 \cdot 8$ & $39^{\circ} 0$ & 0.33 & o \\
\hline$a c u-3(52)^{*}$ & 0 & 0 & $I \cdot 0$ & $24{ }^{\circ} 0$ & 0.40 & 0 \\
\hline$a c u-3(80)^{*}$ & 0 & 0 & $I \cdot I$ & $20 \cdot 0$ & 0.49 & 0 \\
\hline$a c u-3(I 2 I)^{*}$ & 0 & 0 & $\mathrm{I} \cdot 7$ & $20 \cdot 0$ & 0.44 & 0 \\
\hline$a c u-3\left(3^{8}\right)$ & 0 & 0 & $2 \cdot 3$ & $23 \cdot 0$ & 0.39 & 0 \\
\hline
\end{tabular}

* These strains were isolated by mutation from inos-6-8 $A$ and still carried inos; they were grown with an inositol supplement. The other mutants were isolated from ST $A$ and were grown on minimal medium.

\section{Revertant studies}

Since no altered ICL was detected in the original $a c u-3$ mutants, we decided to obtain revertants from them which might produce ICL differing from 'wild-type ICL. in heat-sensitivity or other properties. One hundred and ten revertants were obtained from $a c u-3(I I 5)$ and 29 of these were tested (a) for their heat-sensitivity at $25^{\circ}$ and $37^{\circ}$ when growing on sucrose and on acetate medium, and $(b)$ for the heat-sensitivity of their ICL in vitro at $45^{\circ}$ and $50^{\circ}$.

Three main types of revertant were obtained; two groups, numbering 15 and seven and typified by $115 R 6$ and $I 15 R 20$ respectively, with heat-sensitive forms of ICL; and one group, numbering only two and including $R 48$, with ICL similar to the ST $A$ enzyme (Table 3).

The growth of $115 R 20$ was somewhat depressed on acetate medium at $37^{\circ}$ while $I 15 R 6$ did not grow at all on acetate at this temperature. On sucrose $I 15 R 6$ and $I I 5$ $R 20$ grew equally well at $25^{\circ}$ and $37^{\circ}$. All media were supplemented with inositol since the original acu-3 (II5) strain carried inos. Most of the subsequent work was done on revertant $R 6$.

Fig. I shows the rate of growth of $a c u-3$ (IIS R6), ST $A$ and $a c u-3$ (II5) on acetate, and Fig. 2 shows the heat-inactivation curves for ICL in extracts of $R 6$, ST $A$ and in a mixture of $R 6$ and $\mathrm{ST} A$ extracts. 


\section{Complementation tests on a temperature-sensitive revertant}

Forced heterokaryons were constructed between a double mutant inos acu-3 (II5R6) $A$ strain (isolated in the course of the genetic analysis described in the next section) and two different acu-3 mutants of the original series, acu-3 (22) $\mathrm{A}$ and $a c u-3(38) \mathrm{A}$. These heterokaryons grew on acetate medium without inositol supplement at $25^{\circ}$ at the wild-type rate but failed to grow at all on the same medium at $37^{\circ}$. Thus acu-3 (II5 R6) shows no complementation with either of the ICR-negative acu-3 mutants tested; neither is its expression altered in the heterokaryons.

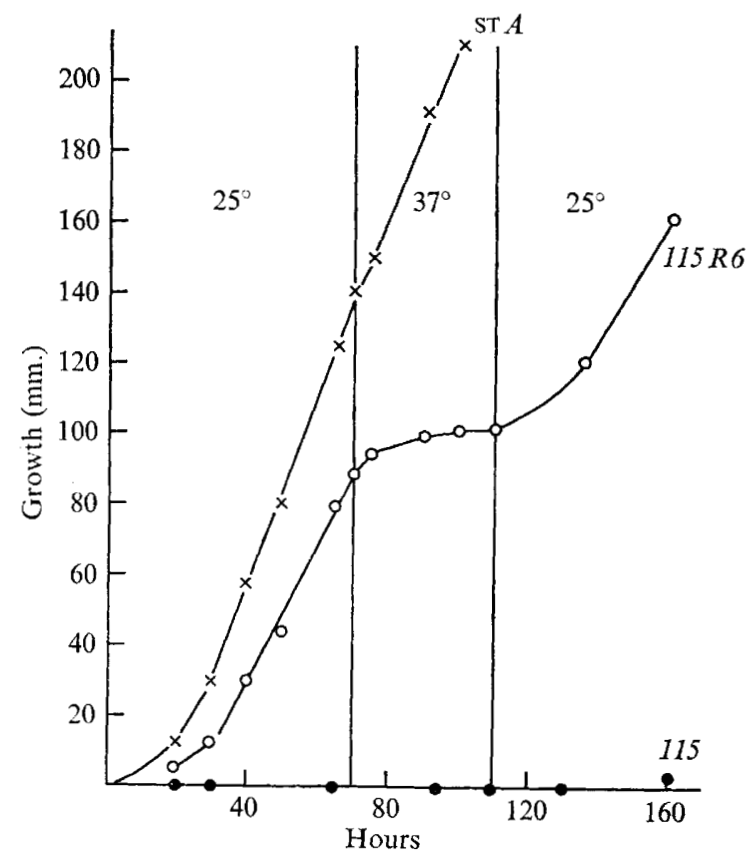

Fig. I

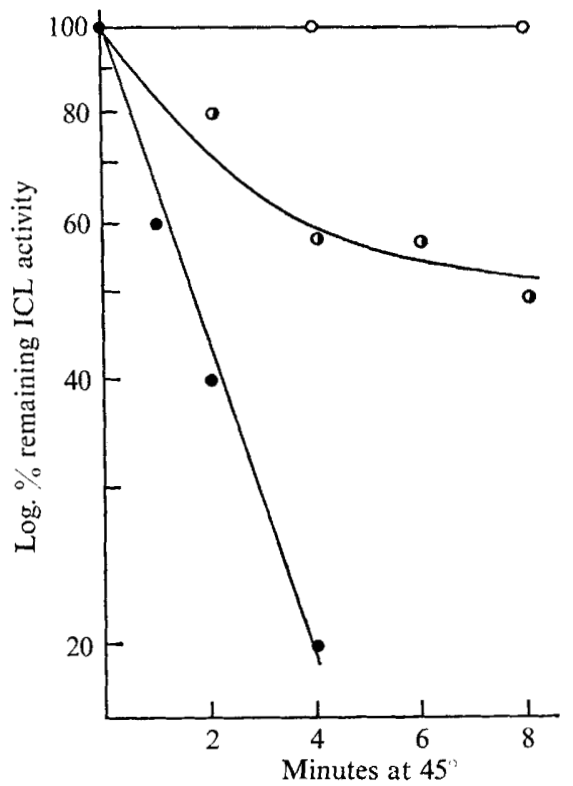

Fig. 2

Fig. I. The growth rates on solid acetate medium at $25^{\circ}$ and $37^{\circ}$ of: ST $A(\times)$, acu-3 (IIS R6) (O), $a c u-3(I I 5)(O)$. Transfers of growth tubes between the $25^{\circ}$ and $37^{\circ}$ incubators were made as indicated.

Fig. 2. The heat-sensitivity at $45^{\circ}$ of ICL from ST $A(O), a c u-3$ (IIS R6) (O), and a mixture of equal amounts of ICL units from sT and $a c u-3(I I 5 R 6)(())$. Theline drawn for the mixture is that expected for independent behaviour of two enzyme species.

Table 3. Growth of revertants at different temperatures and stability of their $I C L$ in vitro

\begin{tabular}{|c|c|c|c|c|c|}
\hline \multirow[b]{2}{*}{ Strain } & & \multicolumn{2}{|c|}{$\begin{array}{l}\text { Growth on acetate } \\
(\mathrm{mm} / \mathrm{h} .)\end{array}$} & \multicolumn{2}{|c|}{$\begin{array}{c}\% \text { Remaining ICL activit } \\
\text { after } 8 \mathrm{~min} \text {. at }\end{array}$} \\
\hline & & $25^{\circ}$ & $37^{\circ}$ & $45^{\circ}$ & $50^{\circ}$ \\
\hline & sT $A$ (wild-type) & $3 \cdot 2$ & $3 \cdot I$ & 100 & 60 \\
\hline $\begin{array}{l}\text { Revertants from } \\
a c u-3(\text { I } 55)\end{array}$ & $\left\{\begin{array}{lll}a c u-3 & (I I 5 & R 6) \\
a c u-3 & (I I 5 & R 20) \\
a c u-3 & (I I 5 & R 48)\end{array}\right.$ & $\begin{array}{l}2 \cdot 2 \\
3 \cdot 0 \\
2 \cdot 2\end{array}$ & $\begin{array}{l}0 \\
2 \cdot 5 \\
2 \cdot 0\end{array}$ & $\begin{array}{r}4 \\
100 \\
100\end{array}$ & $\begin{array}{r}3 \\
22 \\
55\end{array}$ \\
\hline
\end{tabular}




\section{Genetic studies}

If the revertants which produce temperature-sensitive forms of ICL carry suppressor mutations in genes other than $a c u-3$, they should segregate the original $a c u-3$ mutant in $25 \%$ of the progeny if the suppressor is not linked to $a c u-3$, or in lower frequency if there is linkage. Genetic analysis was, however, hampered by the fact that acu-3 ascospores show very poor germination even in sucrose. Even $R 6$ ascospores germinate somewhat less well than wild-type.

Table 4. Genetic analysis of acu-3 (II5 R6) $\left(a c u-3^{t}\right)$

\begin{tabular}{|c|c|c|c|c|c|}
\hline Cross & \multicolumn{3}{|c|}{ Progeny genotypes } & $\begin{array}{c}\text { No. } \\
\text { observed }\end{array}$ & $\begin{array}{c}\% \\
\text { Recombination between }\end{array}$ \\
\hline $\begin{array}{l}\text { inos acu-3t } A \times \\
\quad \text { wild-type } a\end{array}$ & $\left\{\begin{array}{l}a c u-3^{t} \\
+ \\
a c u-3^{t} \\
+\end{array}\right.$ & $\begin{array}{l}\text { inos } \\
\text { inos } \\
+ \\
+\end{array}$ & & $\left.\begin{array}{r}13 \\
4 \\
1 \\
21\end{array}\right\}$ & $a c u-3^{t}-$ inos $=13 \%$ \\
\hline 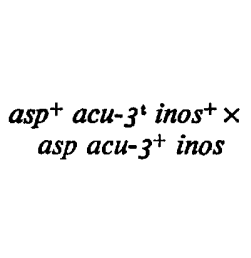 & $\begin{array}{c}\text { asp } \\
+ \\
a s p \\
+ \\
+ \\
\text { asp } \\
+ \\
\text { asp }\end{array}$ & 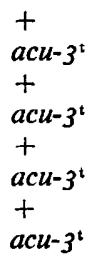 & $\begin{array}{l}\text { inos } \\
+ \\
+ \\
\text { inos } \\
\text { inos } \\
+ \\
+ \\
\text { inos }\end{array}$ & $\left.\begin{array}{r}90 \\
84 \\
28 \\
18 \\
8 \\
8 \\
4 \\
0\end{array}\right\}$ & $\begin{array}{l}\text { asp-acu-3t }=8.3 \% \\
(\text { asp -acu-3 }=6.3 \%)^{*} \\
\text { acu- } 3^{t}-\text { inos }=20.8 \\
(\text { acu-3-inos }=20 \%)^{*} \\
\text { asp-inos }=25.9 \%\end{array}$ \\
\hline
\end{tabular}

* Values previously obtained for acu-3 (Flavell \& Fincham, 1968a).

The $R 6$ phenotype will be represented by symbol $a c u-3^{t}$, a usage which receives some justification from the following results. Spores from inos acu- $3^{t} \times$ ST $A$ were germinated on supplemented sucrose medium at $25^{\circ}$, and 39 spores were tested to determine their genotype. An $a c u-3^{t}$ inos $^{+}$strain from this first cross was then mated with the double mutant asp inos; 240 germinated spores were picked at random and analysed for the presence of acu-3, acu- $3^{t}$, inos and asp. Germination from this cross was about $80 \%$. No $a c u-3$ cultures of the original non-temperature-sensitive type were obtained and nearly half the cultures were $a c u-3^{t}$. The recombination between asp $\left|a c u-3^{t}, a c u-3^{t}\right|$ inos and asp/inos may be compared with the recombination frequencies previously obtained (Flavell \& Fincham, 1967a) between acu-3, inos and asp.

The results in Table 4 indicate that the further mutation in $a c u-3^{t}$ is at least close to the original $a c u-3$ mutation and, in all likelihood, within the same gene.

\section{DISCUSSION}

The production of an altered ICL by each of two kinds of acu-3 revertants is strong evidence that $a c u-3$ is indeed the structural gene for ICL. Both the mapping and the complementation data are consistent with this view. It remains possible that the 'reverse' mutation in $R 6$ activated a normally inactive gene closely linked to $a c u-3$ coding for a separate and more labile species of ICL. It is also not formally ruled out that the $R 6$ mutant could carry a closely linked dominant (or cis-dominant) suppressor, perhaps resulting in the reading of a nonsense codon as a mis-sense codon, though the high efficiency of suppression which would have to be postulated in this case would be 
unusual. Neither of these two alternative hypotheses seems at all likely. The temperature-sensitive nature of the $a c u-3+a c u-3^{t}$ heterokaryons rules out the possibility that the temperature sensitivity could be due to a recessive suppressor mutation.

A surprising result was the failure to find CRM in significant amounts in any of I4 different $a c u-3$ mutants. These mutants probably represent many different sites within the gene since intercrosses among five members of the series gave low frequencies of wild-type recombinants in every cross except one (B.J. Leckie, unpublished). On the basis of results obtained with other structural genes in fungi (Roberts \& Pateman, I964) and bacteria (Margolies \& Goldberger, I968), we had expected that a proportion of the $a c u-3$ mutants would be mis-sense mutations producing CRM. Possibly many of them are the result of nonsense mutations producing drastically shortened (and CRM-negative) polypeptide chains. However, no evidence was found for suppression of any of the $a c u-3$ mutants by Seale's nonsense suppressor $s u$ - $a m^{17}$ (Seale, 1968).

Two forms of ICL have been reported from Neurospora (Sjogren \& Romano, I967) but only one is induced strongly by acetate. The $a c u-3$ gene appears to code for the acetate induced enzyme (ICL-I) and not for ICL-2, since acu-3 arg-Io double mutants have been found to produce appreciable amounts of ICL-2 under the conditions of arginine limitation which have been reported to cause derepression of this enzyme (Flavell \& Woodward, 1970; B. J. Leckie, unpublished).

We are glad to acknowledge advice from Dr D. B. Roberts on the immunochemical tests, and we are also grateful to Mrs Barbara Matthews for technical help. Brenda Leckie held a Research Studentship from the Science Research Council during the course of this work.

\section{REFERENCES}

Davis, B. J. (1964). Disc electrophoresis. II. Method and application to human serum proteins. Annals of the New York Academy of Sciences 121, 404-427.

Dixon, G. H. \& KornberG, H. L. (1959). Assay method for key enzymes of the glyoxylate cycle. Biochemical Journal 72, 3 P.

FinchAm, J. R. S. (1967). Recombination within the am gene of Neurospora crassa. Genetical Research, Cambridge 9, 49-62.

FlaVElL, R. B. \& FinCham, J. R. S. (1968a). Acetate non-utilizing mutants of Neurospora crassa. I. Mutant isolation complementation studies, and linkage relationships. Journal of Bacteriology 95 , ro56-I062.

Flavell, R. B. \& Fincham, J. R. S. (I968 b). Acetate non-utilizing mutants of Neurospora crassa. II. Biochemical deficiencies and the roles of certain enzymes. Journal of Bacteriology 95, 1063-1068.

FLAVELL, R. B. \& WOODWARD, D. O. (1970). The regulation of synthesis of Krebs cycle enzymes in Neurospora by catabolite and end-product repression. European Journal of Biochemistry 13, 548-553.

ITZHAKI, R. F. \& GILL, D. M. (1964). A micro-biuret method for estimating proteins. Analytical Biochemistry 9, 40I-4IO.

MARGOLIES, M. W. \& GoldberGer, R. F. (1968). Correlation between mutation types and the production of CRM in mutants of the $A$ gene of the his operon in Salmonella typhimurium. Journal of Bacteriology 95, 507-519.

OUCHTERLONY, O. (1953). Antigen antibody reactions in gel. Acta pathologica microbiologica scandinavica 32, 231-240.

Roberts, D. B. \& Pateman, J. A. (1964). Immunological studies of amination deficient strains of Neurospora crassa. Journal of General Microbiology 34, 295-305. 
Ryan, F. J., BeAdle, G. W. \& TATum, F. L. (I963). The tube method of measuring the growth rate of Neurospora. American Journal of Botany 30, 784-799.

SEALE, T. (1968). Nonsense suppression in neurospora. Genetics $\mathbf{5 8}, 95$.

SJOGREN, R. W. \& Romano, A. H. (1967). Evidence for multiple forms of isocitrate lyase in Neurospora crassa. Journal of Bacteriology 93, I638-1643.

VoGEL, H. J. (1956). A convenient growth medium for Neurospora. Microbial Genetics Bulletin r3, $42-43$.

WestergaARD, M. \& Mitchell, H. K. (1947). Neurospora: a synthetic medium favouring sexual reproduction. American Journal of Botany 34, 573-577.

WoODWARD, D. O. (I968). Functional and organizational properties of Neurospora mitochondrial structural protein. Federation Proceedings. Federation of American Societies for Experimental Biology 27, 1167-I 173. 